\title{
Investigating atmosphere's environmental components and work environment of a household landfill's platform
}

\author{
Angelica-Nicoleta Găman ${ }^{1 *}$, Alexandru Simion, Marius Kovacs, Izabella Kovacs
}

${ }^{1}$ National Institute for Research and Development in Mine Safety and Protection to Explosion INSEMEX, 32-34 G-ral Vasile Milea Street, Petrosani, Romania

\begin{abstract}
Household landfills can be important sources of air quality contamination if they do not comply with technological sorting and storage procedures. Also, workers' exposure to environmental hazards endangers their health over time. A significant amount of household waste is stored in cells, monthly, after a sorting process that leaves a considerable ecological footprint. In this study we analysed air quality at the boundary of a compliant household landfill, as well as the quality of work environment of landfill's workers. To do this, we performed measurements on two levels (air quality and work environment) over three months, following different phases of waste disposal and different activities involving workers serving the facilities. From an applied perspective, results obtained from research activities provide clear answers to questions related to ways in which environmental components are affected by waste storage activities, and workers are exposed to professional noxious. Results show that the landfill deteriorates environment quality, over time, as well as health of workers. Topic relevance is in connection with its potential future contribution to development of knowledge in the approached field, to be able to quantify progress, once integrated systems for modern ecological collection and storage have legislative regulations.
\end{abstract}

\section{Introduction}

According to the World Health Organization (WHO), air pollution is the biggest environmental risk to human health in the European Union (EU). Although there has been an improvement in air quality, there are still Member States that still do not meet EU standards in this area and have not taken sufficient action to satisfactorily improve air quality. Air pollution runs the risk of being underestimated as it may not be monitored in relevant areas. Often, air quality plans - one of the key requirements of the Ambient Air Quality Directive have not yielded the expected results [7].

Transformation of waste management is closely linked to EU waste legislation. The main legislative instrument in this area is the Waste Framework Directive. It presents a waste

\footnotetext{
* Corresponding author: angela.gaman@insemex.ro
} 
management hierarchy: it starts with prevention, followed by preparation for reuse, recycling and recovery, and ends with disposal. The directive aims to prevent waste generation as much as possible, to use the waste generated as a resource and to minimize the amount of waste that reaches landfills [8].

In the last decade, Romania has made considerable progress in terms of urban waste management within integrated systems for modern ecological collection and storage. In this sense, storage of household waste and assimilated waste in Hunedoara County is carried out only at the compliant Barcea Mare landfill, installed according to legislation and technical norms in force applicable to landfills [1]. Creating this landfill of non-hazardous waste represented a necessity for the county.

Given that municipal solid waste landfills are typical sources of odour pollution that threatens public health and environmental safety [2], this paper sought to quantify pollutants both from the atmosphere and from workplaces on site, to be able to perform a comparative analysis of pollutants with the highest share.

\section{Materials and methods}

Among the activities carried out on site, the following were identified:

a. sources of atmosphere pollution, represented by activities of handling / storage of waste and earth masses, respectively: unloading, transport, levelling. An additional source of dust is wind erosion, a phenomenon that accompanies all these operations, as well as the mobile sources represented by employees' vehicles and waste vehicles;

b. sources of work environment pollution, represented by the waste reception platform, mechanical-biological waste treatment plant (TMB), sorting hall, sorting strip, composting platform, scale.

\subsection{Air quality at the limit of the analysed perimeter}

Regarding the parameters necessary to be monitored, from various possibilities, NO, $\mathrm{NO}_{2}, \mathrm{NOx}, \mathrm{SO}_{2}, \mathrm{O}_{3}, \mathrm{CO}$, suspended particles and to a lesser extent $\mathrm{CO}_{2}$ are of interest both due to the specificity of their presence in the urban environment but also in terms of the detrimental influence they can have on health [3,4].

The equipment used for sampling were those installed on the environmental auto laboratory, endowment of INCD INSEMEX Petroșani, that meet the conditions specified by the European Community directives and the national legislative ones, having operating principles in accordance with standards in force, respectively:

- Horiba APOA-370, an instrument for monitoring ambient air ozone. The determination method is based on photometric analysis (absorption) in UV, at 253.7nm;

- GC-866 airmoVOC (BETEX), a gas chromatograph, for measuring benzene, toluene, ethylbenzene, xylene and other volatile organic compounds in ambient air, respectively, for continuous monitoring of aromatic or halogenated hydrocarbons. The operating principle is flame ionisation detector (FID), automatic sampling with absorbent trap and trap desorption;

- TRS MEDOR GC 866, a gas chromatograph with electrochemical detection for the analysis of sulphur products and derived odorants;

- gas analysers, respectively $\mathrm{CO}, \mathrm{SO}_{2}, \mathrm{NOx}$, which have as operating principles nondispersive infrared spectroscopy (NDIR), ultraviolet fluorescence and chemiluminescence;

- FIDAS 200 dust analyser with optical detection for simultaneous measurement of: PM10, PM4, PM2,5 and total dusts (TSP);

- EVA 700 weather station (speed, pressure, humidity, temperature, global radiation) with an $6 \mathrm{~m}$ telescopic stick;

- high precision GPS with electronic compass, for field location. 
The measured pollutants were: $\mathrm{CO}, \mathrm{SO}_{2}, \mathrm{NO}_{2}, \mathrm{O}_{3}$, benzene, $\mathrm{H}_{2} \mathrm{~S}$ and derived odorants, PM10, PM2.5 and TSP dusts. Immission samples were taken at four cardinal points, given the large area of the site.

In order to perform measurements regarding ambient air quality parameters, with the help of the environmental auto-laboratory, the following steps were observed:
a. Commissioning of the mobile laboratory;
b. Checking and starting the equipment;
c. Sampling;
d. Data transmission;
e. Data processing.

The auto laboratory was positioned at the site's boundary (fig. 1), according to criteria indicated by legislation, measurements being performed in representative areas, for each type of pollutant.

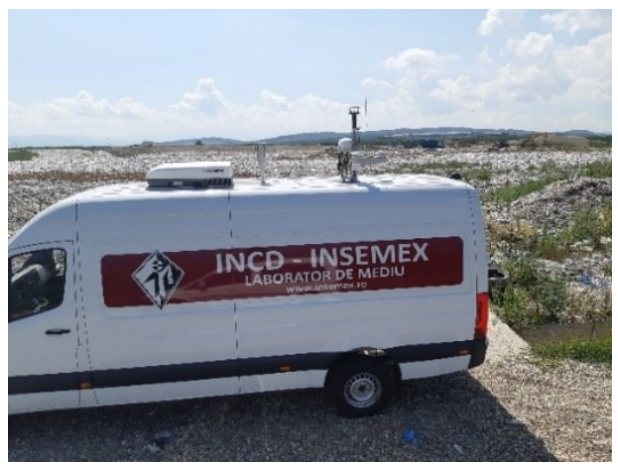

Fig. 1 Positioning of the auto laboratory

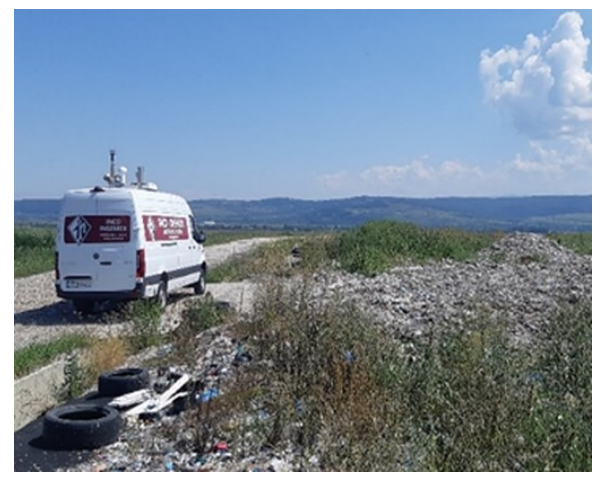

Fig. 2 General sampling collector

Sampling from the ambient air was performed through a general collector (Fig. 2), and sampling of the collected assay is performed automatically, using individual sampling lines fitted with gas-chromatographs and analysers, endowment of the auto laboratory.

In accordance with Law no. 104/2011 on ambient air quality (with subsequent amendments and completions) [5] and STAS 12574-87 [6], determinations were performed for 1 hour, 8 hours, 24 hours or 30 minutes at each measurement point.

\subsection{Air quality in the work environment - exposure of workers to occupational hazards}

Work environment, in which human activity takes place, is characterized by a complex of specific microclimatic and physical-chemical factors, that can negatively influence the health of employees.

The methodology for assessing exposure to occupational hazards [9] involves the following successive steps:

- Preliminary knowledge;

- Sampling stage;

- Analysis stage;

- Comparing to "permissible" exposure limits. 


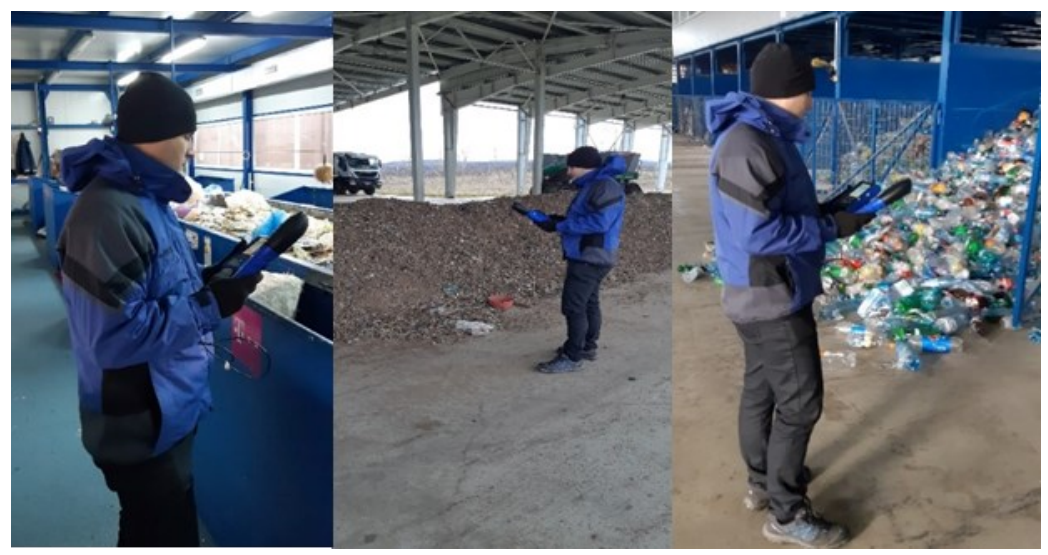

Fig. 3 Noxae sampling

Monitoring of individual exposure is performed with the help of portable sampling systems, with global quantitative analysis and for each chemical noxious substance.

Sampling systems: GrayWolf and Kimo AMI 300 devices were used in the monitoring activity, each having a certain measuring range. GrayWolf devices provide measurement and data transmission of over 30 parameters using DirectSense ${ }^{\circledR}$ probes (Fig.1.5), AdvancedSense ${ }^{\circledR}$ meters and WolfPack ${ }^{\circledR}$ sensors including VOCs, carbon dioxide, suspended particles, humidity, atmospheric pressure, wind speed, ozone, ammonia, formaldehyde, nitrogen dioxide etc. The GrayWolf PC-4000 Particle / Mass Monitor Plus device (Fig.4) is intended for monitoring suspended dust, which can be configured for shortterm sampling or for continuous, long-term data recording. It can measure particles with dimensions from $0.3 \mu \mathrm{m}$ to $25 \mu \mathrm{m}$.
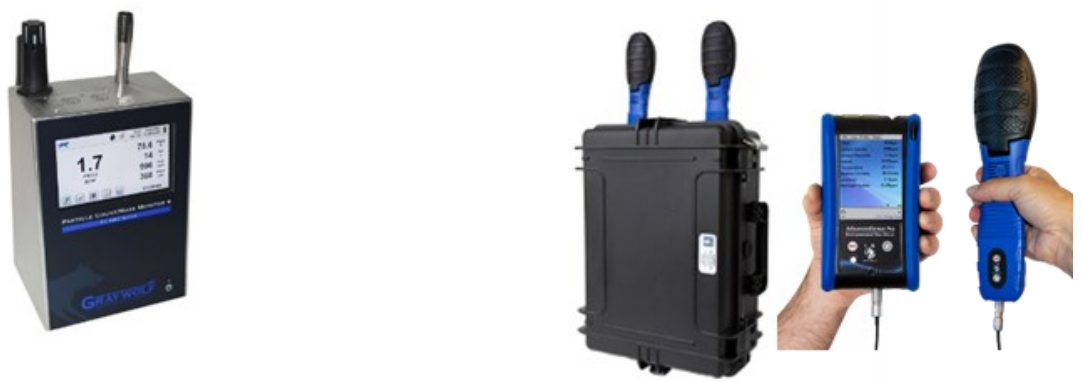

Fig. 4 GrayWolf PC-4000 device

Fig. 5 DirectSense II smart probes

The equipment used to collect pollutants from workplaces complies with national / international standards, measurement protocol observes the procedures held by the laboratory, each working method being validated.

\section{Results and discussion}

A team of specialists from the Environmental Laboratory carried out several measurement campaigns at the household waste landfill under study, where they performed measurements 
on two levels, respectively: atmospheric air and workplace atmosphere air. The measurements were performed over 6 months, the current paper only showing results of only two months of measurements, for relevant reasons of space and number of pages allocated to research.

The 4 cardinal points where air quality measurements were performed were:

- Storage room (NW) - Point 1

- Storage room (SE) - Point 2

- Location limit NE (N: $\left.45^{\circ} 48^{\prime} 26.1 " \mathrm{E}: 22^{\circ} 58^{\prime} 14.9^{\prime \prime}\right)$ - Point 3

- SE location limit (N: $\left.45^{\circ} 48^{\prime} 30.7^{\prime \prime E}: 22^{\circ} 58^{\prime} 40.9^{\prime \prime}\right)$ - Point 4

We mention that the mobile air pollutants analysis laboratory is aligned with the most modern and new techniques in the field, equipment in its endowment ensuring facilities for rapid measurement of physical-chemical indicators. It also offers the possibility to determine a large number of indicators that can be determined in-situ for air environment components.

Table 1 Results of air quality monitoring at the boundary of the landfill site, year 2020

\begin{tabular}{|c|c|c|c|c|c|c|c|c|c|}
\hline \multirow{2}{*}{ Component } & \multirow[b]{2}{*}{ Unit } & \multicolumn{4}{|c|}{ FEBRUARY } & \multicolumn{4}{|c|}{ MAY } \\
\hline & & Pet.1 & Pct. 2 & Pct.3 & Pct.4 & Pet.1 & Pct.2 & Pct.3 & Pet. 4 \\
\hline PM 2.5 & {$\left[\mu \mathrm{g} / \mathrm{m}^{3}\right]$} & 5,81 & 3,31 & 3,02 & 14,29 & 11,66 & 7,95 & 8,18 & 10,54 \\
\hline PM 10 & {$\left[\mu \mathrm{g} / \mathrm{m}^{3}\right]$} & 6,87 & 6,58 & 5,79 & 17,87 & 20,22 & 12,57 & 12,34 & 16,98 \\
\hline PM Total & {$\left[\mu \mathrm{g} / \mathrm{m}^{3}\right]$} & 8,13 & 11,34 & 7,48 & 25,68 & 28,04 & 19,42 & 18,65 & 24,79 \\
\hline $\mathrm{CO}$ & {$\left[\mathrm{mg} / \mathrm{m}^{3}\right]$} & 0,279 & 0,193 & 0,433 & 0,3842 & 0,1850 & 0,3648 & 0,4104 & 0,3252 \\
\hline $\mathrm{O}_{3}$ & {$\left[\mu \mathrm{g} / \mathrm{m}^{3}\right]$} & 85,51 & 62,95 & 56,67 & 41,85 & 50,86 & 64,78 & 38,63 & 61,79 \\
\hline $\mathrm{NO}$ & {$\left[\mu \mathrm{g} / \mathrm{m}^{3}\right]$} & 18,42 & 8,71 & 18,11 & 11,16 & 36,26 & 34,53 & 27,91 & 22,69 \\
\hline $\mathrm{NO}_{2}$ & {$\left[\mu \mathrm{g} / \mathrm{m}^{3}\right]$} & 6,26 & 5,42 & 4,72 & 13,15 & 18,33 & 16,78 & 15,37 & 5,68 \\
\hline $\mathrm{NO}_{\mathrm{X}}$ & {$\left[\mu \mathrm{g} / \mathrm{m}^{3}\right]$} & 24,68 & 14,13 & 22,83 & 24,31 & 54,59 & 51,31 & 43,28 & 28,37 \\
\hline $\mathrm{SO}_{2}$ & {$\left[\mu \mathrm{g} / \mathrm{m}^{3}\right]$} & 14,49 & 15,72 & 18,77 & 14,89 & 8,38 & 7,46 & 16,29 & 11,32 \\
\hline DMS & [ppb] & 8,76 & 9,22 & 4,73 & 4,58 & 10,97 & 27,91 & 6,37 & 1,29 \\
\hline ETHYL-SH & [ppb] & 6,49 & 3,88 & 5,78 & 4,25 & 7,58 & 11,57 & 7,27 & 5,16 \\
\hline $\mathrm{H}_{2} \mathrm{~S}$ & {$\left[\mathrm{mg} / \mathrm{m}^{3}\right]$} & 0,021 & 0,023 & 0,009 & 0,010 & 0,020 & 0,025 & 0,006 & 0,005 \\
\hline $\begin{array}{l}\text { METHYL- } \\
\text { SH }\end{array}$ & {$\left[\mathrm{mg} / \mathrm{m}^{3}\right]$} & 0,195 & 0,140 & 0,036 & 0,040 & 0,335 & 0,299 & 0,082 & 0,034 \\
\hline Temperature & {$\left[{ }^{\circ} \mathrm{C}\right]$} & 2,25 & 6,32 & 7,39 & 3,12 & 16,11 & 18,56 & 18,48 & 12,19 \\
\hline $\begin{array}{l}\text { Solar } \\
\text { radiation }\end{array}$ & {$\left[\mathrm{W} / \mathrm{m}^{2}\right]$} & 89,88 & 252,81 & 138,74 & 40,73 & 802,3 & 374,09 & 229,98 & 354,55 \\
\hline Pressure & [mbar] & 951,29 & 941,58 & 924,68 & 926.46 & 991,6 & 985,5 & 986,24 & 949,08 \\
\hline Humidity & {$[\% \mathrm{RH}]$} & 75,84 & 60,15 & 80,36 & 89,63 & 67,97 & 71,36 & 88,97 & 74,81 \\
\hline $\begin{array}{l}\text { Wind } \\
\text { direction }\end{array}$ & $\begin{array}{l}{[\mathrm{NV}]} \\
{[\mathrm{SE}]}\end{array}$ & 70,83 & 45,55 & 69,18 & 102,78 & 29.3 & 164.96 & 149,73 & 221,7 \\
\hline Wind speed & {$[\mathrm{m} / \mathrm{s}]$} & 0,298 & 0,315 & 0,257 & 0,326 & 0,785 & 0,642 & 0,453 & 0,818 \\
\hline & $\begin{array}{l}\text { u: } E T H \\
M E T H \\
D M S- \\
P M-p c\end{array}$ & $\begin{array}{l}\mathrm{H}-\epsilon \\
\mathrm{SH}- \\
\text { ethy }\end{array}$ & $\begin{array}{l}\text { nerca } \\
\text { yl me } \\
\text { hide } \\
\text { er }\end{array}$ & & & & & & \\
\hline
\end{tabular}

For carbon monoxide samples collected were of short (30 minutes / 1 hour) and medium duration ( 8 hours), taken on days without precipitation.

The highest concentration was recorded for methyl mercaptan, during the discharge and compaction of waste and for hydrogen sulphide.

In conclusion, based on the acquired and validated data, the level of pollution in the monitored area was low, as follows:

a. all hourly average values were framed below the alert thresholds for sulphur dioxide, nitrogen dioxide and ozone and respectively below the information threshold for ozone; 
b. all values of daily averages for PM10, PM2.5 and 8-hour daily averages for CO framed in normal limits;

c. in the area of the landfill, the relevant source of pollution is represented by road traffic (garbage trucks coming from the county), its intensity determining moments when concentration peaks appear, for specific monitored pollutants - $\mathrm{CO}, \mathrm{NO}, \mathrm{NO}_{2}$, benzene and PM10;

d. exceeding of the concentration of the long-term daily average for methyl mercaptan $\left(\mathrm{CMA}=0.00001 \mathrm{mg} / \mathrm{m}^{3}\right)$;

e. exceeding of the concentration of the short-term average (30 minutes) for hydrogen sulphide $\left(\mathrm{CMA}=0.015 \mathrm{mg} / \mathrm{m}^{3}\right)$.

Table no. 1.1 shows that the odorants methyl mercaptan and hydrogen sulphide, regardless of season (winter, spring), exceed the allowed limit. Moreover, measurements performed in 2019 (throughout the year), in the same sampling points imposed by the environmental permit, but performed for a short period (30 minutes), showed the same exceedances. Thus, the Territorial Environment Agency required the economic operator to perform measurements over long periods ( 24 hours) and to take measures to reduce these concentrations in the environment.

Because the ecological landfill is located at a distance of approximately $5 \mathrm{~km}$ from the nearest household, no complaints have been made by the inhabitants.

At workplaces in the landfill, occupational hazard measurements were performed at the following points:

- Waste reception platform - Point 1

- Waste sorting station - Point 2

- Picking belt - Point 3

- Compost platform - Point 4

Table 2 Results of measured average air quality values in the working environment on the landfill platform, year 2020

\begin{tabular}{|c|c|c|c|c|c|c|c|c|c|}
\hline \multirow[b]{2}{*}{ Component } & \multirow[b]{2}{*}{ Unit } & \multicolumn{4}{|c|}{ FEBRUARY } & \multicolumn{4}{|c|}{ MAY } \\
\hline & & Pct.1 & Pct.2 & Pet.3 & Pct.4 & Pct.1 & Pct. 2 & Pct.3 & Pct.4 \\
\hline $\mathrm{Cl}_{2}$ & {$\left[\mathrm{mg} / \mathrm{m}^{3}\right]$} & 0.177 & 0.194 & 0.218 & 0.168 & 0.167 & 0.212 & 0.180 & 0.163 \\
\hline $\mathrm{NO}_{2}$ & {$\left[\mathrm{mg} / \mathrm{m}^{3}\right]$} & 0.101 & 0.066 & 0.052 & 0.057 & 0.053 & 0.119 & 0.098 & 0.072 \\
\hline $\mathrm{CO}_{2}$ & ppm & 279.4 & 269.4 & 383.7 & 312.7 & 399.6 & 484.8 & 677.1 & 387.5 \\
\hline $\mathrm{CO}$ & {$\left[\mathrm{mg} / \mathrm{m}^{3}\right]$} & 1.42 & 0.34 & 2.10 & 0.05 & 0.58 & 0.44 & 1.18 & 1.74 \\
\hline $\mathrm{O}_{3}$ & {$\left[\mathrm{mg} / \mathrm{m}^{3}\right]$} & 0.060 & 0.062 & 0.048 & 0.061 & 0.021 & 0.067 & 0.078 & 0.033 \\
\hline $\mathrm{NH}_{3}$ & {$\left[\mathrm{mg} / \mathrm{m}^{3}\right]$} & SLD & SLD & 0.02 & SLD & 0.02 & SLD & 0.19 & 0.01 \\
\hline $\mathrm{SO}_{2}$ & {$\left[\mathrm{mg} / \mathrm{m}^{3}\right]$} & 0.021 & 0.004 & 0.002 & 0.017 & 0.025 & 0.005 & 0.148 & 0.068 \\
\hline $\begin{array}{l}\text { PH3 } \\
\text { (phosphine) }\end{array}$ & {$\left[\mathrm{mg} / \mathrm{m}^{3}\right]$} & 1.142 & 1.077 & 0.817 & 1.135 & 0.466 & 0.525 & 0.677 & 0.513 \\
\hline $\begin{array}{l}\text { Oxid ethylene } \\
(\text { EtO) }\end{array}$ & {$\left[\mathrm{mg} / \mathrm{m}^{3}\right]$} & SLD & SLD & SLD & SLD & 40.06 & 39.82 & 39.55 & 39.97 \\
\hline Fluor (F2) & {$\left[\mathrm{mg} / \mathrm{m}^{3}\right]$} & 0,033 & 0,022 & 0,050 & 0,026 & 0,080 & 0,037 & 0,022 & 0,063 \\
\hline $\mathrm{H}_{2} \mathrm{~S}$ & {$\left[\mathrm{mg} / \mathrm{m}^{3}\right]$} & 0.088 & 0.128 & 0.079 & 0.113 & 0.123 & 0.064 & 0.078 & 0.108 \\
\hline TVOC & [ppb] & SLD & SLD & SLD & SLD & 0.75 & 0.072 & 1.83 & 0.51 \\
\hline Temperature & {$\left[{ }^{\circ} \mathrm{C}\right]$} & 5.78 & 6.11 & 18.35 & 5.45 & 21.09 & 23.05 & 24.24 & 20.33 \\
\hline Pressure & [mbar] & 987 & 986 & 986 & 987 & 989 & 990 & 989 & 989 \\
\hline Humidity & {$[\% \mathrm{RH}]$} & 63.35 & 66.18 & 29.68 & 68.08 & 59.96 & 58.24 & 59.76 & 47.14 \\
\hline
\end{tabular}

Samples collected were of short duration (15 minutes) for most of the pollutants and of long duration (8 hours) for $\mathrm{CO}_{2}$ and ethylene oxide, according to GD 157/2020.

Results in Table 2, show that all workplaces record exceedances for phosphine (PH3) in the two months of monitoring and also, all workplaces record exceedances for ethylene oxide in May. 
Phosphine is a gas exhaled by waste that probably contains this indicator. Because of its high degree of toxicity, the substance is a major health problem for workers. The toxic gas called phosphine is a gas that cannot be detected by the human senses, being odourless and tasteless $[10,11]$. The routes of human contamination are respiratory, digestive or, less frequently, cutaneous. When phosphine is inhaled it will reach the lungs, from where it will be taken up in the blood. The toxic effect is proportional to the amount reaching the body, but also to exposure time.

Ethylene oxide is used as a sterilizing gas for various foods, pesticides and consumables in medical processes or as an intermediate for the manufacture of other chemicals [11]. Moreover, in small amounts, ethylene oxide is used as a pesticide and as a sterilant in food additives to eliminate bacterial Salmonella contamination of food. In this sense, its presence in municipal waste is explained. Uncontrolled emissions from municipal waste, creates exposure of workers to this gas, classified by the European Chemicals Agency (ECHA) as mutagenic (causes changes in genetic structure), carcinogenic (causes cancer) and toxic to reproductive functions.

Therefore, workers' exposure to ethylene and phosphine oxide must be kept to a minimum. Given that at the analysed workplaces there is no activity for more than two hours a day, the exposure is minimal, but not to be neglected. The territorial labour inspectorate has so far not imposed measures to monitor workplaces or reduce risks for this economic operator.

\section{Conclusions}

- In the project within the Nucleu Program - EXTOX 2, monthly measurement campaigns of atmospheric air quality parameters were carried out on the platform of a compliant household landfill, corroborated with quality parameters of work environment, in order to establish the field of pollutant concentrations and workers' exposure to occupational hazards. In this regard, samples of gases' immissions and dusts from the atmosphere were sampled, as well as occupational noxae from the work environment. This paper presents results of two months of monitoring out of a total of the 6 months;

- Analysing the results shows that at the site, the air is polluted mainly by hydrogen sulphide and methyl mercaptan, which also generate odours felt by residents in the area, and the predominant pollutants in the workplace are phosphine and ethylene oxide. In this sense, no indicator was observed to be polluting both analysed places, these being independent, depending on the activity carried out on the platform and the type of waste deposited;

- Results show that, over time, the landfill deteriorates environment quality as well as health of workers.

- Compliance with "exposure limits" and "maximum permitted values" is a good legislative tool for controlling the working environment and air quality for health management of exposed employees, as well as of population in the area;

- The effects induced on environmental components in the vicinity of the landfill, as well as on health of workers on the waste platform, show the need to include appropriate measures to prevent emissions into the air, as well as regular monitoring of those measures to prevent spills, discharges, incidents or accidents during the use of equipment / facilities and storage. In order to detect possible pollution of air and other environment components at an early stage and, therefore, to take appropriate corrective measures before the spread of pollution, a permanent monitoring of the landfill is necessary.

This paper was developed within the Nucleu-Program, carried out with the support of MCI, Nucleu Program EXTOX 2, entitled "Modernization of research infrastructure for complete 
investigation of both physical-chemical parameters of environmental components quality of waste landfills, as well as of work environments in order to increase the degree of safety and health".

\section{References}

1. INCD INSEMEX Petrosani, Specialized study on the current situation of municipal landfills in Hunedoara County (2018)

2. A.N. Călămar, L. Toth, S. Simion, M. Kovacs, 9th Edition of the International Symposium on Occupational Health and Safety - SESAM, Research on the advantages of in situ investigation of air quality parameters by means of environmental auto laboratories, (Petrosani, Romania, 2019)

3. A.N. Călămar, G.A. Găman, L. Toth, S. Simion, I. Kovacs, Proceedings Ecology, Economics, Education and Legislation , 5.1, 75-81(2020)

4. M. Moufid, B. Bouchikhi, C. Tiee, M. Bouchikhi, N. El Bari, Atmospheric Environment, 256, (2021)

5. Law no. 104 on ambient air quality (2011)

6. STAS 12574:87, Air from protected areas, Quality conditions, (1987)

7. https://op.europa.eu/webpub/eca/special-reports/air-quality-23-2018/ro/

8. https://www.eea.europa.eu/ro/semnale/semnale-de-mediu-2014/articole/deseurile-oproblema-sau-o-resursa

9. M. Kovacs, L. Toth, G. Ghetie, A. Draghici, T. Vasiu, G. Laurentiu, Environmental Engineering and Management Journal, 13, 1421-1426, (2014)

10.C. Tomescu, M. Prodan, N Vatavu, E. Chiuzan, Environmental Engineering and Management Journal, 16, 1389-1393, (2017)

11. A. Szollosi-Mota, M. Prodan, I. Nalboc, C. Tomescu, I. Krausz, Environmental Engineering and Management Journal, Volume 11, 1323-1330, (2012) 